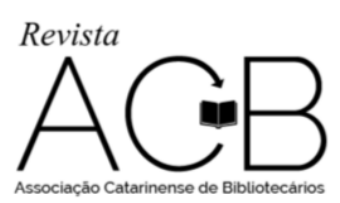

\title{
A DISSEMINAÇÃO DA INFORMAÇÃO: O PAPEL DO BIBLIOTECÁRIO-MEDIADOR
}

\author{
Diego Andres Salcedo ${ }^{1}$ \\ salcedo.da@gmail.com \\ Jhoicykelly Roberta Pessoa e Silva² \\ kellypessoa2@hotmail.com
}

\begin{abstract}
Resumo: Destaca a mediação da informação como sendo a atividade primordial do bibliotecário. A trajetória da prática biblioteconômica a partir de duas vertentes: "preservação" e "disseminação". Analisa a biblioteca como um instrumento cultural - a variedade de sua funcionalidade social. Salienta como frequentemente há um obscurecimento diante do papel daquele que é o agente precípuo da biblioteca e que, independentemente de sua especialidade, da instituição ou do suporte de informação com o qual trabalha, o bibliotecário é um mediador e que a preservação pode submeter-se a disseminação e não ao contrário.
\end{abstract}

Palavras-chave: Mediação. Bibliotecário. Informação.

\section{INTRODUÇÃO}

Embora não seja algo frequentemente discutido pelas pessoas em seu cotidiano, todos parecem ter uma opinião formada sobre qual é a função de um bibliotecário. Parece ser comum, por exemplo, admitir que a profissão não tenha qualquer lugar na sociedade atual e que, de algum modo, com o crescente avanço tecnológico sua existência tenha se tornado secundária.

Ao contrário do que imaginam, todavia, essa opinião reflete ainda mais a necessidade da existência do bibliotecário no interior do corpus social. A aparente facilidade ao acesso da informação difundida pela internet, por exemplo, acabou por contribuir para que as opiniões do senso comum sobre a importância desse profissional distanciem-se cada vez mais da realidade.

O bibliotecário seguiu as premências da sociedade, adequando-se ao avanço tecnológico e expandindo sua função para além das fronteiras da biblioteca. Ele passou a ocupar não somente cargos nos mercados tradicionais - bibliotecas públicas, universitárias, escolas, centros culturais e arquivos -, mas a fazer parte de uma variedade de outros setores que estão diretamente ou indiretamente conectados com a informação - empresas privadas, bancos e bases de dados digitais, portais de conteúdo e em redes institucionais internas. Isso tudo, portanto, demonstra a necessidade de trazer de volta o debate sobre a função desse profissional e explicitá-la de tal modo que as opiniões do senso comum não obscureçam a sua imagem.

Traçando uma rápida análise do seu perfil no contexto histórico, podemos compreender os motivos pelos quais o bibliotecário ganhou os estereótipos que escondem a sua verdadeira importância

\footnotetext{
${ }^{1}$ Doutorado em Comunicação pela Universidade Federal de Pernambuco. Mestrado em Comunicação pela Universidade Federal de Pernambuco. Graduado em Biblioteconomia pela Universidade Federal de Pernambuco. Professor do Departamento de Ciência da Informação na Universidade Federal de Pernambuco.

${ }^{2}$ Graduanda em Biblioteconomia pelo Departamento de Ciência da Informação na Universidade Federal de Pernambuco.
} 


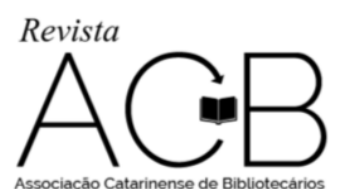

A disseminação da informação: o papel do bibliotecário-mediador Diego Andres Salcedo e Joicykelly Roberta Pessoa e Silva

social. A partir do momento em que a sociedade percebeu a conveniência de legitimar o bibliotecário como uma profissão, este passou a se adequar as questões pertinentes ao seu tempo.

Deste modo, o presente artigo discute a questão da mediação da informação como sendo o papel fundamental que perpassa a profissão do bibliotecário e que atribui a sua relevância dentro da sociedade. Para isso, pretenderemos demonstrar como a base das suas atividades está centrada na disseminação da informação, pois esta é a sua principal função. Para alcançar nossos objetivos desenvolveremos uma pesquisa bibliográfica, compreendendo e a aprofundando os conceitos e suas aplicações.

\section{O CONTEXTO HISTÓRICO DO BIBLIOTECÁRIO: DISSEMINAÇÃO E PRESERVAÇÃO}

Podemos observar que na trajetória histórica da biblioteconomia, prevalece uma opinião de que bibliotecário tem como função basilar a preservação dos acervos para que venham se conservar por um longo período de tempo (RANGANATHAN, 2009). Isso se deu, sobretudo, como uma herança que lhes foi herdada da necessidade de preservar o conhecimento para a posteridade.

Algumas práticas de outrora podem enfatizar tal perspectiva: nos primeiros séculos da Idade Média, por exemplo, as coleções monásticas se restringiam exclusivamente aos que pertenciam as ordens religiosas (MILANESI, 2013); em meados do século XV, por sua vez, o ato de acorrentar os livros nas estantes confinava a liberdade dos seus acessos em detrimento da disseminação da informação (RANGANATHAN, 2009).

Essas práticas acabaram por incutir no bibliotecário a ideia de que a biblioteca tem o Paradigma Custodial e Patrimonialista ${ }^{3}$ - provocando constantemente a clivagem entre ela e a sociedade. Ademais, por ser utilizada inicialmente por um grupo específico da sociedade que geralmente detinha o conhecimento, foi propagada a falsa concepção de que os mais afastados do "saber" não podiam acessá$1 \mathrm{a}^{4}$. Essa atitude acabou por construir nas sociedades posteriores a visão de que elas não tinham direito aquele ambiente. Ainda hoje essa visão persiste, embora por motivos distintos dos períodos anteriores: a tecnologia atribuiu à ilusão de que a biblioteca tornou-se um ambiente desnecessário ${ }^{5}$.

Entretanto, uma análise mais detalhada dessa opinião - em contraste com a prática a qual o bibliotecário exerce - pode nos revelar outro tipo de perspectiva. Já se faz pouco mais de um século que se teve início o debate sobre a formação desse profissional (CASTRO, 2000), colocando em análise dois tipos essenciais de concepção: o "técnico" e o "humanista". Essa análise teve como característica

\footnotetext{
3“'O paradigma Custodial e Patrimonialista desenvolveu-se, sobretudo, a partir de uma formação localizada e centrada no locus profissional (Arquivos, Bibliotecas e Museus), com suas tarefas e exigências práticas que se sobrepunham a eventuais preocupações teóricas e reflexivas" (SILVA, 2010).

${ }^{4}$ Conforme Almeida Junior (2004. p. 72): “[...] a biblioteca também foi e continua sendo vista como dissociada dos interesses da maioria da sociedade; como um equipamento cultural que contribui para a perpetuação de uma estrutura em que o saber é ferramenta para ampliação das desigualdades; como uma instituição cujas ações reforçam e ampliam o fosso entre os que possuem e os que não possuem informação".

${ }^{5}$ Conforme parece indicar o artigo "O Retrato da exclusão digital na sociedade Brasileira” escrito por Lília Almeida, Luiza Paula, Flávio Carelli, Tito Lívio e Marcelo Genestra (2005).
} 


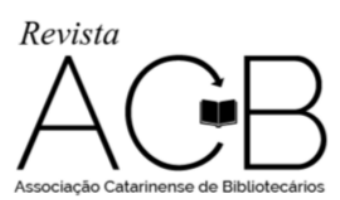

essencial fazer-nos refletir sobre a herança que foi legada ao bibliotecário e, por conseguinte, estabelecer um novo tipo de função que perpassa toda a prática do profissional.

$\mathrm{O}$ século XX trouxe à discussão um novo tipo de perspectiva que até então parecia passar despercebida ao bibliotecário - é o que hoje indicamos como Paradigma Pós-Custodial ${ }^{6}$. Com a explosão quantitativa da informação (LE COADIC, 2004), o profissional passou a pensar a biblioteconomia como ciência e a tentar resolver os problemas de recuperação para atender melhor os usuários.

Pela primeira vez, os usuários tornaram-se o objeto principal de trabalho do bibliotecário - na medida em que a biblioteca adquire a premência de pensar novos paradigmas que auxiliem nas demandas oriundas das vastas produções científicas:

ao longo do século XX, contudo, o desenvolvimento de reflexões e teorias nas três áreas [biblioteconomia, arquivologia e museologia] não conduziu ao fortalecimento do modelo dominante [tecnicista]. Ao contrário, a vasta produção cientifica que se seguiu, identificou, com muita frequência, os vários limites desse modelo, ressaltando diversos aspectos que, pouco a pouco, foram conduzidos a necessidades de sua superação (ARAUJO, 2014, p. 16).

Destarte, a partir das discussões entre ambas as formações, o papel do bibliotecário pode, sobretudo, entrelaça-las para utilizar os procedimentos técnicos de recuperação da informação, não para a sua preservação, mas para a sua disseminação ao usuário. É preciso, antes de tudo, esclarece a definição de "mediação da informação" - que até então é discutida apenas na teoria e pouco colocada efetivamente em prática (ALMEIDA JUNIOR, 2009). Segundo Almeida Junior (Idem, Ibid), a definição mais $\operatorname{adequada}^{7}$ para o conceito de "mediação da informação" deve ser aquela que leva em consideração:

toda ação de interferência - realizada pelo profissional da informação -, direta ou indireta; consciente ou inconsciente; singular ou plural; individual ou coletiva; que propicia a apropriação de informação que satisfaça plena ou parcialmente, uma necessidade informacional.

A partir da análise do contexto histórico do bibliotecário podemos perceber que após séculos efetuando o trabalho de guarda e preservação, ele se deparou com a necessidade de disseminar a informação para a sociedade. No capítulo seguinte, buscaremos investigar o papel da mediação na atuação desse profissional, assim como os seus espaços de atuação.

\footnotetext{
${ }^{6} \mathrm{O}$ paradigma pós-custodial, como aponta Miranda, tem como missão "fundamentar o campo da Ciência da Informação com uma carga teórica, de progressiva evolução, tornando perceptível que a documentação e a biblioteconomia formem as bases identitárias (sic) desse campo" (2012, p. 56).

${ }^{7}$ Embora a definição proposta por Almeida Junior seja a que, de fato, concordemos, existem outros modos (inclusive mais atuais) de compreender o conceito de "mediação da informação".
} 


\section{O BIBLIOTECÁRIO-MEDIADOR E SEUS ESPAÇOS DE ATUAÇÃO}

Para além do senso-comum construído pela sociedade e comumente atribuído ao bibliotecário ${ }^{8}$, existe a opinião velada e ainda mais perigosa do profissional que, em vez de tentar combater os estereótipos que lhes são atribuídos, acaba por dar margem para que se fortaleçam ainda mais.

Dentre a variedade de possibilidades a qual o profissional encontra-se preparado para tomá-la como objetivo de especialização, o bibliotecário - motivado por opiniões exteriores - acaba por seguir apenas os caminhos em que sua profissão é reconhecida. Não é raro manifestar um desejo pelos setores que reconheçam a importância de sua função e, embora isso seja uma atitude justificável, acaba por inviabilizar a contemplação de sua missão social (ORTEGA Y GASSET, 2006).

Vemos, por exemplo, um maior número de bibliotecários trabalhando nas áreas médicas, jurídicas, empresas privadas e, em último lugar, na área de educação. Essa afirmação ganha forças, sobretudo, nas palavras de Almeida Junior (2004, p. 75):

o bibliotecário, segundo essa concepção, passa a ser um profissional voltado para um pequeno e seleto segmento social, embora hegemônico quanto aos instrumentos ideológicos de exclusão social, que domina. Os espaços onde atua são concebidos e estruturados para atender a uma demanda oriunda daqueles que já tem acesso à informação.

Essa atitude acaba por engendrar outro problema: ao se encontrar inserido em um desses âmbitos específicos de trabalho, o bibliotecário resume todas as suas atividades técnicas na tentativa de facilitar a sua própria recuperação e não a do usuário, isto é, o foco de suas ações submete-se a preservação dos acervos e não a disseminação da informação. Independente do momento histórico e das mudanças científicas no percurso da história, os bibliotecários retornam sempre ao mesmo ponto: excluem a possibilidade dos usuários adquirirem sua própria autonomia de busca (ASHIM, 1982 apud BRIQUET DE LEMOS, 2006).

Essa concepção ganha forças, sobretudo, na medida em que analisamos o fazer do profissional em seu ambiente de trabalho. Parece ser uma opinião de parte dos profissionais que o processo de mediação da informação está apenas vinculado a ambientes específicos, como a biblioteca escolar - através da mediação de leitura no processo de contação de histórias -, e ao Serviço de Referência - "que é o que mantém o contato mais próximo dos usuários de uma unidade de informação" (SILVA, 2005, p. 3). Se

\footnotetext{
8“A sociedade não conhece exatamente as funções exercidas por um bibliotecário; não pode fazer uso dos espaços que ele atua; precisa de um mínimo de habilidades para obter algo que considere útil dentro do que é armazenado e oferecido nas unidades de informação; o conteúdo vinculado nos suportes informacionais são codificados de maneira a dificultar sua compreensão (a norma culta, as referências e linguagens imagéticas, tanto fixas como em movimento, a linguagem do som); revela seu total desconhecimento do fazer bibliotecário quando elege, para descrever o profissional, características que são consideradas por ele como deturpadas e discrepantes e, relação a verdadeira imagem.” (ALMEIDA JUNIOR, 2004, p. 84).
} 


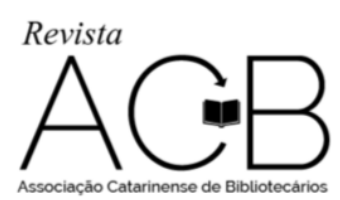

analisarmos, contudo, cada um dos tipos de bibliotecas, podemos descobrir que a mediação da informação não se restringe ao lugar de trabalho do profissional.

Claro que na biblioteca escolar isso parece ser mais evidente, pois o aluno, mediado pelo bibliotecário, busca a biblioteca para "satisfazer suas necessidades, quer imediatas quer não, oriundas de demandas próprias ou ditas por estratégias pedagógicas" (ALMEIDA JUNIOR, 2004, p. 76). As demandas próprias, entretanto, devem ser mais bem acolhidas pelo mediador, pois uma vez que as crianças estão no processo de formação, o bibliotecário-mediador ${ }^{9}$ irá orientá-la na construção de sua formação como cidadão.

Mas o processo de mediação deve ser visto para além do ambiente escolar: na biblioteca universitária, por exemplo, a mediação é efetuada a partir do processo de orientação dos estudantes tanto na literatura básica exigida pelo curso, quanto na literatura mais aprofundada que o auxiliará na sua autonomia intelectual como futuro pesquisador.

Para Milanesi (2013, p. 69), o bibliotecário-mediador das bibliotecas universitárias pode ser:

o especialista que torna a especialidade acessível. Por isso, aquele que atua, por exemplo, numa faculdade Medicina ou de Música deve ter domínio da área para poder dialogar com os pesquisadores e, principalmente, tornar mais acessível para os iniciantes os caminhos do saber médico ou musical.

No caso das inúmeras variações das bibliotecas especializadas, há uma diferença: o público, diferente dos demais tipos supracitados, sabe o que quer. Ele muitas vezes tem o domínio da biografia, destituindo o que interessa e o que deve ser descartado (Ibid). Quando isso não ocorre, entrementes, é o dever do bibliotecário-mediador fornecer a orientação e expandir os horizontes de possibilidades que o usuário especialista pode obter.

Por exemplo, um jurista que não conhece bases de dados de instituições que fornecem fontes formais legislativas, doutrinárias e jurisprudenciais, o bibliotecário poderá contribuir lhe informando a existência e até indicando possíveis acervos que venham a melhor lhe informar sobre os assuntos.

No caso da biblioteca pública, o público é tão heterogêneo quanto à informação, isto é, os acervos são destinados a todo tipo de pessoas - tanto as que sabem o que querem, quanto as que não sabem. No quadro com os tipos de bibliotecas propostas por Milanesi (Ibid, p. 112), o autor acaba por designar o nível de complexidade das bibliotecas públicas - em comparação com as demais - como altíssima, graças a enorme variedade de temas.

A ação do bibliotecário-mediador nesse ambiente demonstra-se fundamental, por conta da larga expansão do seu público: ele deve, sobretudo, saber trabalhar com as diferenças socioeconômicas das

\footnotetext{
${ }^{9}$ No interior do presente trabalho, o termo "bibliotecário-mediador" abarca as diferentes habilidades que se vinculam às atividades de informação. Conforme relembra Mota e Oliveira (2005, p. 99) a partir de Mueller (2004) “é consensual a ideia de que, mesmo que esses profissionais possuam origem em várias e diferentes áreas do conhecimento, é necessária a existência de algumas características mínimas que lhes sejam comuns".
} 


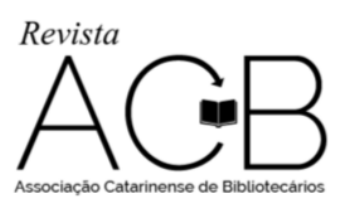

pessoas e, por meio do processo de mediação (que não se restringe apenas a isso), indicar as obras a qual cada grupo é destinado ${ }^{10}$.

A mediação da informação, portanto, não ocorre apenas nos âmbitos supramencionados, ela vai para além do contado direto com o público - chegando também aos processos técnicos. Ela encontra-se em todo e qualquer fazer do bibliotecário. A partir do momento em que o profissional cria qualquer tipo de mecanismo de recuperação da informação, sua ação será voltada sempre aos usuários:

A mediação da informação permite e exige concepção de informação que desloque o usuário da categoria de mero receptor, colocando-o como ator central do processo de apropriação. Dessa forma, defendemos que o usuário é quem determina a existência ou não da informação. A informação existe apenas no intervalo entre o contato da pessoa com o suporte e a apropriação da informação (ALMEIDA JUNIOR, 2009, p. 97).

Desse modo, podemos inferir que assim como o aluno é possui o papel fundante na existência do professor, o usuário é o objeto principal de toda ação do bibliotecário. A seguir, efetuaremos uma análise na importância da profissão para o desenvolvimento da sociedade.

\section{O PAPEL DO BIBLIOTECÁRIO-MEDIADOR PARA O DESENVOLVIMENTO DA SOCIEDADE}

A informação, por ser um fenômeno puramente social construído num contexto sócio-históricocultural definido e a partir de certa época, pode ser compreendida como um bem inteiramente coletivo, na medida em que "as pessoas a utilizam em suas atividades sociais, educacionais e culturais, exercendo seu direito à cidadania" (MOORE, 1997 apud VARELA, 2007, p. 31).

O processo de mediação mencionado por VARELA (2007) é constituído da seguinte maneira: de um lado, temos a figura do bibliotecário que é emissor da informação; o canal que é a fonte a qual a informação é adquirida e, do outro lado, o usuário como o receptor da informação. É preciso que o bibliotecário compreenda que essa estrutura vai sofrer variáveis, isto é, a instituição pode não ter a fonte de informação que o usuário procura ou que ele não possua conhecimento suficiente para que a mensagem circule entre ele e o emissor:

a mensagem que circula entre o emissor e o receptor somente pode ser compreendida se os dois polos pressupõem de um repositório comum de signos para que não se produzam distorções (...) Alguns obstáculos de codificação/decodificação são provocados pela instituição que transmite a mensagem; os outros, de caráter técnico, provêm da forma de tratamento e de transferência da informação; outros, de caráter sociopsicológico, estão ligados às relações entre usuários e especialistas da informação; outros, finalmente, são de caráter ideológico e político (Ibid, p. 35).

\footnotetext{
${ }^{10}$ Essa concepção lembra a segunda e a terceira lei de RANGANATHAN que determina para "cada leitor seu livro" e para “cada livro seu leitor”. (2009, p. xi).
} 


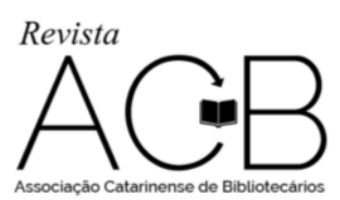

No caso da ausência de demanda dos usuários, os bibliotecários precisam elaborar estratégias para atraí-los de volta - tendo a preocupação de não afastar os que ainda permanecem usando frequentemente a biblioteca. A mediação, nessa etapa, passa a auxiliar no processo de recuperação da informação pelo público. A partir do momento em que o usuário é bem atendido - tanto pelo profissional, quanto pela instituição - haverá uma maior possibilidade de que este retorne a usar os serviços. Quando isso ocorrer, entretanto, é importante que o bibliotecário-mediador esteja disposto a acolhê-lo para que, desse modo, ele volte a satisfazer sua necessidade.

Se certa demanda planejada for atingida, então a natureza da mediação não deve ser alterada. O bibliotecário-mediador deve permanecer dando atenção aos usuários - "otimizando" seu tempo na medida em que o auxilia na busca. Ademais, uma vez que o bibliotecário mostra uma preocupação em atender as necessidades dos usuários, a qualidade de sua imagem como profissional muda, independente do setor social no qual trabalhe.

Os usuários que, até então, passavam a não valorizar a sua importância, o verão como necessário na construção de seu desenvolvimento. Deste modo, a profissão do bibliotecário deverá estar preocupada, em primeiro lugar, com a mediação da informação, pois uma vez que a mediação se transforma em seu escopo de trabalho, o bibliotecário acaba por transformar o ambiente ao qual se encontra inserido.

\section{CONSIDERAÇÕES FINAIS}

Apesar do que foi proposto no presente artigo, no sentido de um debate sobre a função social do bibliotecário, muito deve ser discutido. As práticas exercidas por este profissional mostram-se pertinente, na medida em que muito se tem versado erroneamente sobre a sua relevância para o corpus social.

O bibliotecário, antes de todos, deverá ser quem pensa na sua função. Pensar na mediação, portanto, é um meio para se alcançar um fim. Esse fim não deve ser a informação, mas, sobretudo, o usuário. Independente da sua especialidade, do suporte informacional e do local onde ele trabalha, o bibliotecário é um mediador - submetendo os processos técnicos em favor da disseminação da informação.

\section{REFERÊNCIAS}

ALMEIDA JUNIOR, Oswaldo Francisco de. Profissional bibliotecário: um impacto com o excludente. In: BAPTISTA, Sofia Galvão; MUELLER, Suzana Pinheiro Machado (Org.). Profissional da Informação: o espaço de trabalho. Brasília - DF: Thesaurus, 2004. p. 70-86.

Mediação da informação e Múltiplas linguagens. Tendências da pesquisa Brasileira em Ciência da Informação, Brasília,v. 2.,n. 1., 2009. Disponível em: <http://goo.gl/1Z2ocD>. 


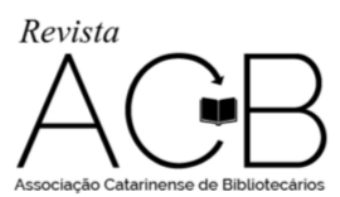

ALMEIDA, Lília Bilati; CARELlI, Flávio Campos; OSÓRIO, Tito Lívio Gomes, et al. O retrato da exclusão digital na Sociedade Brasileira. JISTEM, São Paulo, v. 2.,n. 1., 2005. Disponível em: 〈http://goo.gl/0GLP9w〉.

ARAÚJO, Carlos Alberto Ávila. Arquivologia, Biblioteconomia, Museologia e Ciência da Informação: o diálogo possível. Brasília, DF: Briquet de Lemos, 2014.

BRIQUET DE LEMOS, Antonio Agenor. Circunstâncias e recepção de 'Missão do Bibliotecário'. In: ORTEGA Y GASSET, JOSÉ. Missão do bibliotecário. Brasília: Briquet de Lemos, 2006. p. 59-82.

CASTRO, César Augusto. História da Biblioteconomia Brasileira: perspectiva histórica. Brasília: Thesaurus, 2000.

LE COADIC, Yves-françois. A ciência da informação. Brasília: Briquet de Lemos, 2004.

MIRANDA, M. K. F. O. O custodialismo e a teoria da intencionalidade. Recife: Néctar, 2012.

MILANESI, Luiz. Biblioteca. 3. ed. Cotia: Ateliê, 2013.

MOTA, Francisca; OLIVEIRA, Marlene. Formação e atuação profissional. In: Ciência da Informação e Biblioteconomia: novos conteúdos e espaços de atuação.Belo Horizonte: Ed. da UFMG, 2005. p. 97-110.

ORTEGA Y GASSET, JOSÉ. Missão do bibliotecário. Brasília: Briquet de Lemos, 2006. p. 59-82.

RANGANATHAN, S. R. As Cinco Leis da Biblioteconomia. Brasília: Briquet de Lemos, 2009.

SILVA, Armando Malheiro da. Mediações e mediadores em Ciências da Informação. Prisma.com, n. 9.,p. 1-37, 2010.

SILVA, Ezequiel Theodoro da. A dimensão pedagógica do trabalho do bibliotecário. In: Leitura na escola e na biblioteca. 10. ed. Campinas: Papirus, 2005. p. 67-83.

SILVA, Fabiano Couto Corrêa da. Bibliotecários especialistas: guia de especialidade e recursos informacionais. Brasília: Thesaurus, 2005.

VARELA, Ainda. Informação e Construção da Cidadania. Brasília: Thesaurus, 2007.

\title{
INFORMATION DISSEMINATION: THE ROLE OF MEDIATOR LIBRARIAN
}

\begin{abstract}
Highlights the mediation of information as the primary activity of the librarian. The trajectory of library Science practice from two aspects: "preservation" and "dissemination". Analyzes the library as a cultural instrument - the variety of its social functionality. Highlights how often there is a clouding facing the role of what is the preciputagente of the library and regardless of their specialty, the institution or the information carrier with which it Works, the librarian is a mediator and that preservation may be subject to spread and not the opposite.
\end{abstract}

Keywords: Mediation. Librarian. Information. 